\title{
RESENHA DE LIVRO
}

RAVITCH, Diane.The Language police: how pressure groups restrict what students learn. New York: Ed. Alfred A. Knoff, 2003. 255 p.

O material didático produzido nos Estados Unidos nos últimos quarenta anos sofreu mudanças profundas. Novos modos de organizar as informações e maior riqueza nas ilustrações dão aos modernos livros escolares uma aparência muito diferente de livros e outros recursos de ensino produzidos até os anos de 1960. Diane Ravitch, autora de The Language Police descobriu, porém, que as mudanças mais profundas não são nem didáticas, nem gráficas. As mudanças mais profundas são fruto de uma censura crescente praticada por órgãos de governo e pelas editoras.

A autora tomou contato com o problema ao verificar que muitos textos indicados por um comitê nacional do qual ela fez parte foram excluídos de um teste elaborado por uma agência do governo federal. Ravitch quis saber por quê. E a partir desse interesse descobriu que uma censura silenciosa vem atingindo desde a década de 1970 a confecção de testes de desempenho escolar, produção de livros didáticos e processos de aquisição de literatura para as bibliotecas das escolas.

O primeiro capítulo de $\boldsymbol{T}$ The Language Police elenca diversos exemplos de escritos que foram excluídos de testes de leitura. As exclusões não foram motivadas por questões de mérito literário. Foram motivadas por razões psicológicas, sociais e políticas. Alguns textos foram recusados porque continham palavras ou situações que poderiam criar embaraço para algum grupo de alunos. Ódio era uma das palavras censuradas. Divórcio, uma situação excluída. Motivos para cortar trechos supostamente problemáticos ou excluir completamente certas histórias beiravam o absurdo. Em caso examinado por Ravitch, um texto de boa qualidade literária não pode ser utilizado porque se referia a uma montanha nevada. O comitê revisor argumentou que esta particularidade geográfica prejudicaria o desempenho de crianças da planície em regiões de clima temperado, uma vez que tais crianças não possuíam experiência de vida compatível com o cenário apresentado pelo texto. Uma história sobre coruja foi censurada. Argumentou-se que aquele pássaro é tabu para um dos povos indígenas da América do Norte.

A mesma política de censura está presente nos livros escolares. $\mathrm{Na}$ medida em que grupos de pressão, à direita e à esquerda, observam possíveis vieses em obras didáticas, as editoras se apressam a retirar do texto palavras ou conteúdos que possam ter algum teor de controvérsia. Para evitar prejuízos e, ao mesmo tempo, conquistar indicação de suas obras nos maiores estados do país (sobretudo Texas e Califórnia), os produtores de material didático se preveniram, elaborando manuais que definem com muita precisão o que deve ser evitado. Ravitch apresenta um anexo com uma relação de interdições presentes na maioria dos manuais utilizados pelas editoras. Tais interdições abrangem palavras (termos que possam, segundo os grupos de pressão, lembrar etnocentrismo, predomínio dos homens em qualquer ativida- de, visão pessimista quanto à velhice, rótulo desfavorável quanto a pessoas com alguma diferença física ou neurológica etc.), situações (menção a fato ou cena que possa desfavorecer qualquer grupo na sociedade), ilustrações (desenhos, fotos ou figuras que não retratem de modo preciso a distribuição estatísticas de todos os segmentos populacionais). Além disso, exige-se que certos grupos sejam sempre apresentados de modo a não lembrar determinados estereótipos.

Assim, mulheres não podem ser retratadas de avental ou fazendo serviço doméstico, pessoas idosas não podem ser mostradas em cadeiras de balanço, pessoas negras não podem ser mostradas no exercício de profissões pouco prestigiadas. Cabe notar que não há interdição para figuras de homens vestindo aventais ou realizando trabalhos domésticos. Os manuais aconselham apresentar mulheres realizando atividades antes identificadas como masculinas, idosos exercitando-se em academias, negros exercendo profissões socialmente valorizadas.

Algumas das justificativas para a revisão de materiais didáticos são frutos de conquistas sociais no campo dos direitos civis. $\mathrm{E}$ elas certamente são um alerta importante para que se evitem equívocos que podem estar presentes em materiais didáticos. Mas a prática de revisão foi longe demais. Deixou de lado qualquer traço de bom senso e passou a ser um processo que incorpora, sem crítica, mudanças sugeridas por pressão de lobistas de todas as origens. Uma prova disso é a proibição de mencionar a teoria da evolução em livros didáticos, exceto os de ciências biológicas. A exclusão do tema evolução de livros de leitura para atender à pressão de religiosos fundamentalistas mostra uma tendência que tem um único nome: censura.

Diane Ravitch destaca duas áreas de saber muito prejudicadas: literatura e história. Em literatura, os revisores exigem textos e ilustrações que levem em consideração as representações estatísticas de cada grupo social. Isso abrange autores e enredos. Ótimas antologias foram criticadas e até excluídas do mercado por falta de números adequados de autores representando mulheres, negros, latinos etc., não importando méritos literários. Nos enredos e ilustrações é preciso retratar fielmente a estatística. Excluem-se assim textos clássicos ou de boa qualidade literária para atender conveniências de representação populacional. A autora descobriu que as práticas de censura acabaram atingindo clássicos da literatura. Emprega-se no caso, um procedimento que recebe o nome de bowdlerização (bowdlerization). Tal procedimento foi utilizado no começo do século XIX pelos irmãos Bowdler e consistia na exclusão de trechos que, segundo critérios moralistas, implicasse em prejuízo ético ou promoção de maus costumes. Os citados 
irmãos reeditaram com tal orientação obras de Shakespeare, delas excluindo passagens ou palavras que consideravam ofensivas. A bowderização é muito comum em antologias para fins escolares. Um dos casos mais chocantes de bowderização aconteceu com Ray Bradbury. O editor de uma antologia escolar queria que o autor excluísse de um de seus contos palavras que comitês revisores de vieses consideram inadequadas. O mencionado editor, acostumado a adaptar textos para que estes se ajustem a demandas dos grupos de pressão, provavelmente ignorou a crítica severa de Bradbury á censura em Fahrenheit 451.

Em história, as revisões para verificar possíveis vieses sacrificam evidências para dar lugar ao politicamente correto. Excessivo cuidado em promover culturas de outros continentes acaba ignorando importantes contribuições da Europa. Preocupações com representações de todos os segmentos sociais acabam retratando, de modo duvidoso, mulheres, negros e minorias em eventos históricos muito distantes de nosso tempo. Para escapar do problema e usando a linguagem genérica da descrição de objetivos educacionais, em muitos estados americanos os documentos de padrões curriculares deixam de mencionar qualquer conteúdo de história. Os citados documentos especificam que os alunos devem ser capazes de pesquisar, avaliar informação, descobrir relações, resolver problemas etc. Mas são omissos quanto a conteúdos históricos.

Em muitas das situações examinadas pela autora, há uma constatação inquietante: os atos de censura costumam articular-se com ideais de escolanovismo e com a pedagogia das competências. O resultado de tal articulação é um esvaziamento crescente de conteúdos nos materiais didáticos. Com a censura, qualquer assunto controverso é afastado do ambiente escolar. Divórcio, violência urbana, desemprego, pobreza e outras realidades que ocupam o noticiário dos meios de comunicação desaparecem dos livros didáticos sanitizados. Esse resultado é congruente com a ênfase sobre o local preconizada pela Escola Nova. O escolanovismo alia-se também com preocupações de eliminar qualquer conteúdo cuja generalidade contrarie a orientação de atender supostas necessidades imediatas dos alunos. Como já se observou com relação a materiais para ensino de história, atos de censura são muitas vezes reforçados por uma tendência que desconsidera a importância dos conteúdos. Os livros didáticos escritos de acordo com restrições ditadas por lobistas de todos os tipos perdem cada vez mais conteúdos. Mas esse esvaziamento acaba não sendo percebido se os materiais incluírem exercícios e abordagens didáticas que, supostamente, favorecem o desenvolvimento de habilidades e competências definidas por padrões curriculares análogos aos que estamos acostumados a ver na maioria dos nossos PCN's.

O panorama traçado por Diane Ravitch mostra um empobrecimento crescente dos materiais didáticos e atos condenáveis de censura. É um engano achar que a obra diz respeito apenas aos EUA. Sintomas de censura já são bem visíveis no Brasil e em outros países. Além de condenações de livros didáticos, comandadas por grupos de direita, observa-se em nosso país certa "vigilância pedagógica" para proibir uso escolar de determinadas obras literárias. Recentemente, uma professora de idiomas teve de suspender leitura de Robison Crusoe porque uma pedagoga acusava o autor, Daniel Defoe, de racista. Essa, provavelmente, não é uma atitude isolada. A censura no campo de materiais didáticos já chegou por aqui.

The Police of Language merece atenção por abordar de um modo bastante original conseqüências de críticas ideologicamente engajadas aos materiais didáticos. A autora mostra que, à esquerda e à direita, a ação de vigilantes pode resultar numa censura geralmente ignorada por pais e professores. Como costuma ser auto-imposta pelo mercado editorial, tal censura não é transparente. Com os avanços nas áreas de estudos da aprendizagem e da comunicação, espera-se que as mudanças nos materiais de ensino sejam frutos de melhorias cientificamente informadas. Dificilmente imagina-se que novas formas de censura acabem influindo de modo decisivo o conteúdo dos recursos didáticos. Por isso, o livro de Ravitch é um alerta que não pode ser ignorado.

Jarbas Novelino Barato Professor. Mestre em Tecnologia Educacional pela San Diego State University (SDSU). Doutor em Educação pela Universidade Estadual de Campinas (UNICAMP) 